\title{
Philippe Gréciano \& John Humbley (dir.) 2011. Langue et droit : terminologie et traduction. Vol. XVI, 2011-1 de la Revue Française de Linguistique Appliquée. 136 pages, ISSN 1386-1204
}

\section{Introduction}

The volume XVI of the Revue Française de Linguistique Appliquée (RFLA) is called "Langue et droit : terminologie et traduction". Indeed, the relationship between law and language is sui generis as both are normative and culture-bound systems. Legal discourse and legal texts are at the same time law's main resource and object because "language is the medium, process and product in the various arenas of the law" (Maley 1994: 11). The performative function of legal language is characteristic of certain genres of legal discourse and does not exist, at least to the same extent, in other specialized domains such as computing and medicine. If law has an intimate relationship with language, this also means that legal discourse produced by one linguistic community may differ from that produced by a different one. Also, law is unusual in being system-bound because even if many different countries use the same language to convey and make law, "each country has its own legal language representing the social reality of its specific legal order" (Šarčević 1985: 127). When working with legal texts written in more than one language, translators and terminologists are thus often faced with the challenge of having to deal with the anisomorphism of the linguistic and legal systems involved.

Having as its main objective the study of language and legal texts, Jurilinguistics emerged in the bilingual and bijural Canada with the publication of Langage du droit : Essais de Jurilinguistique (1982) by Jean-Claude Gémar. Jurilinguistics is said to be the scientific study of legal language. Gémar explains that "la jurilinguistique est une réponse aux difficultés, aussi variées que nombreuses, que la cohabitation, sur un même territoire, des langues et des systèmes juridiques ne pouvait manquer de créer" (2005: xv). However, in Europe, Gérard Cornu (2005) argues that Jurilinguistics is a hypothesis of research rather than a science à part entière and prefers the term linguistique juridique (the title of his work published in 1990) because it includes not only the study of legal language but also the study of linguistic rights precluded from the realm of Jurilinguistics.

In the presentation of this volume, the directors, Philippe Gréciano and John Humbley, state that they wish to make a contribution to the topic of the language of law by presenting a selection of papers within the framework of applied linguistics that express the viewpoint of French-speaking authors. They explain that legal discourse is a legitimate research topic in applied linguistics because it combines the expertise of both linguists and legal experts and that only specialized journals published in northern countries have dedicated special numbers to this topic, namely the journals Fachsprache in Germany and Hermes in Denmark. It is most likely for this reason that this volume contains papers written by French-speaking authors from all over the world: Jean-Claude Gémar and Mathieu Devinat from Canada, Abolou Camille Roger from the Ivory Coast, Mathieu Guidère and Philippe Gréciano from France, Alain Guillaume from Haïti, Hendrik Kockaert and Frieda Steurs from Belgium. The exceptions to this are the contribution written in English by Simon Taylor, an Englishman working at the Université Paris-Diderot, and the contribution written in German by the legal expert Philippe Gréciano.

In this review, we will try to demonstrate that the articles are not limited to the relationship between law and language. They rather describe how the trinity law-language-society makes legal terminology and translation a challenge, this raising the debate on universalism vs. relativism. Thus, we will argue that this collective contribution is more in line with the type of work that goes by the name of Jurilinguistics than the type of work that goes by the name of linguistique juridique. 


\section{Summary of contents}

The volume is organized into two parts. The first part contains 10 articles written by the aforementioned authors. The second part includes four reviews of books published in 2010: a review by John Humbley of I.A. Araguas et al.'s Translating justice. Traducir la justicia; a review by Françoise Gadet of M. Francard et al.'s Dictionnaire des belgicismes; a review by Thierry Fontenelle of H. Béjoints's The Lexicography of English; and a review by Victorine Hancock of L.S. Florea and C. Fuchs' Dictionnaire des verbes du français actuel : constructions, emplois, synonymes.

The first article is written by Jean-Claude Gémar and is called "Aux sources de la "jurilinguistique" : texte juridique, langues et cultures". The author reminds the reader that, in Canada, translation has contributed to the understanding of the interplay between language and culture, this giving rise to Jurilinguistics. According to him, Cornu's Linguistique juridique (1990) as well as the work that Philippe Gréciano and John Humbley have developed, namely the present volume of the RFLA, are all good practices of Jurilinguistics. Jean-Claude Gémar refers to some of the other articles published in the volume such as those written by Abolou Camille Roger, Mathieu Devinat, Mathieu Guidère, and Simon Taylor, he discusses the issues raised by them and concludes that jurilinguists can play a role in yeasting the universalism of law. In fact, this ideal permeates several articles of the volume.

Abolou Camille Roger writes about "Le discours juridique en Afrique noire. Terminologie et traduction du droit". In Black Africa, three different legal systems, i.e. customary law, civil law and common law, as well as different languages coexist, this creating a cacophony of discourses. The author presents the problem in terms of "discursive configurations" (situational, semiotic and cryptotypical) and mechanisms of transfer of law. The situational configuration refers to legal discourse produced in a given situation (marriage, adoption, witchcraft, etc.). The semiotic one relates to the "jurisignes" defined as "néologisme forgé sur le modèle de jurisculture (Legrand 1999), un signe juridique, de nature linguistique, paralinguistique ou non linguistique" (p. 2021). Legal discourse may have a cryptotypical configuration when it is conveyed orally or by means of images or symbols. For interlegal translation, Abolou Camille Roger proposes a balance between functionalism and laxity by means of three methodological approaches that he oddly names terminographic, ontoterminological and terminological. He says the first one consists in gathering documentation on the legal systems; the second consists in identifying "les universaux linguistiques"; and the last one consists in translating the universals according to the sociocultural and linguistic specificities of societies. Although the methodology seems legitimate, it is not clear why the author chose these appellations as we understand terminography rather as "part of terminology work concerned with the recording and presentation of terminological data" (ISO 1087-1) and ontoterminology as "a terminology whose terms, either of usage or normalised, are related to concepts defined in a formal ontology" (Roche et al. 2009). Like Jean-Claude Gémar, Abolou Camille Roger seems to believe that the hybridism of legal norms in a more and more globalized world will slowly give rise to the universalism of law.

Mathieu Devinat presents "Le bijuridisme et le bilinguisme canadiens : des idéaux sous tension". Canada is known for its official bijuralism and bilinguism. As a bilingual Quebecker, Mathieu Devinat explains very clearly why the co-existence of bijuralism and bilingualism creates tensions. Some federal laws contain terms referring both to civil law and common law, because federal law is neither an autonomous nor a complete system. Due to the presence of two linguistic communities, i.e. French and English, official laws are published in two languages and the two versions have the same legal status. When judges are called upon to interpret and apply laws in a uniform way despite the two different legal systems and linguistic communities, problems arise when the French and English versions differ. Under certain circumstances, judges are allowed to choose one version in detriment of the other (for instance, one of them is less ambiguous or more specific), but the judges' own linguistic background can condition the way they interpret laws. The author gives the example of a case in which the accused could be found guilty if the English version of 
a given article of the Criminal Code had been considered and not guilty had the French version been preferred. Difficulties notwithstanding, for Mathieu Devinat the solution seems to be the following: Canadian legal experts, especially judges, have to master the cultures and terminologies of both common law and civil law.

In "La médiation humanitaire multilingue. Un discours pour la paix" Mathieu Guidère talks about the skills interpreters should develop while playing the role of mediators to help alleviate or solve problems of a humanitarian nature, for example in the Arab world. In order to be neutral and, most of all, to make the parties in dispute switch attitudes of violent confrontation to those of pacific exchange, mediators should master techniques of multilingual and intercultural communication. The methodology which the author proposes includes the study of culture-specific cognitive scenarios or cultural scripts which help mediators make a diagnosis of the conflict and act appropriately.

In the article entitled "Kampf gegen den Terrorismus. Rechtsprache im (Kon)Text", Philippe Gréciano analyses the origin of the term terrorism, compares definitions of the term by studying European legislation as well as antiterrorist discourse and concludes that the distinction between terrorism and resistance is not easy to establish. Terrorism is a polysemous term whose meaning has evolved. The author mentions the Terreur lived during part of the French revolution, die Rote Armee Fraktion in Germany, the Guerillas in South America as well as many other historic episodes that have not always been considered as terrorism but that could well be considered as such nowadays. All the examples that he uses are indeed very different in nature (religious, political, etc.) and make the reader question the limits between the right to freedom and the fight against terrorism. Because terrorism is so difficult to define, there is no single European legislation harmonizing national ones. Therefore, the author argues for a global definition of terrorism and international justice when countries like the USA, Germany and France have been fighting against the so-called terrorism in Afghanistan since 2002 and several other configurations and episodes of terrorism do not cease to appear.

Alain Guillaume's paper is called "L'expression créole du droit : une voie pour la réduction de la fracture juridique en Haiti" and is dedicated to the colleagues who died in the 2010 Haïti earthquake. In Haïti, the majority of people speak one language only, i.e. Haïtian Creole, but French remains the language of law and administration. Alain Guillaume explains that dichotomies have always reigned in this country in which bijuralism (civil law and customary law) is aggravated by the underrating of Haïtian Creole. When it gained the status of official language alongside with French in 1987, measures to let Haïtian people have access to laws and official documents in Creole were not immediately promoted. To make matters worse, he says, authorities decided to have normative texts translated instead of opting for co-drafting. Due to the lack of language resources in Creole, translators have a hard time translating certain legal concepts and therefore frequently use neologisms and produce translations with dubious quality. Although an anti-constitutional hierarchy between target text and source texts arises out of this, not everything is negative in the panorama drawn by Alain Guillaume. Creole language can sometimes be more specific than French to the point that translators are able to clarify certain passages in the translated text that were ambiguous in the French version.

Hendrik J. Kockaert and Frieda Steurs present "Un outil de gestion terminologique pour la traduction juridique en Belgique : état de la question et perspectives". This is really a work in progress as the authors concentrate more on the state of the art than on the advancement of the project consisting in a legal terminology management system (TMS) for translators in Belgium, a country in which the same legal system is used by three different linguistic communities (French, Dutch and German). The authors account for the decisions that they had to make so that the design of the TMS meets the users' needs. One of the most important requirements for them is the inclusion of contexts illustrating the terms. They compare databases as different as WordNet, the dictionary by the Canadian PAJLO, a dictionary by the Law Faculty of the University of Liège, the Belgian 
SEMAMDY, and the Canadian Juriterm. One wonders why they did not include in the comparison the Canadian Termium or the European IATE, although this would not change much the conclusions the authors reach: none of these databases consistently provide contexts illustrating terms nor their phraseologies. For all these reasons, the project by Kockaert and Steurs is relevant in that they propose to extract and align the contexts of terms, to differentiate between term synonyms, to validate data, and to make all the information available to users in the easiest way possible.

In the article "European Union and National legal Languages: an Awkward Partnership?", Simon Taylor explains why multilingualism continues to pose challenges to the harmonization process carried out by the European Commission (EC). He illustrates his point with reference to directives. Directives are one of the forms of legislation that must be transposed by each Member State and, as a result, they have to be translated, usually from English or French, into all twenty-three official languages. Under European law, national courts have to interpret national legislation in compliance with Community law. Although each language version has equal status, some language versions of the directives can diverge due to the typical problems of legal translation. Not only is the translation of legal concepts from one language version to another problematic because some legal concepts (principles, institutions, reasoning, etc.) are culture-bound, but also each country has its own style of legislative drafting. For all these reasons, the European Court of Justice plays an important role in minimizing divergence by promoting the harmonized interpretation of EC law. Simon Taylor provides many examples illustrating every point he makes, which contributes to the clarity of the paper. The article is also extremely relevant given the crisis that Europe is currently facing. In a moment when the economic situation of Europe is being heatedly debated, Simon Taylor's contribution proves that differences between all Member States are not limited to the better or worse behaviour of the economies of each Member State. What is at stake here is the political configuration model of the European Union that urgently needs to be redefined as well as a balance between relativism and universalism.

The last article, "Critique de la traduction dans les procès Khmers Rouges", was written by Philippe Gréciano, one of the directors of the volume. The author accounts for the role of translation in the Khmers Rouge case, in which Khieu Samphan, president of Democratic Kampuchea (Cambodia) between 1976 and 1979 as well as a participant in the Khmer Rouge movement, was charged with crimes against humanity, war crimes and genocide. Unfortunately, Philippe Gréciano does not give details on the specificities of the Khmer Rouge tribunal, formally known as the Extraordinary Chambers in the Courts of Cambodia (ECCC), which began its judicial activities in 2007 and tried Khieu Samphan. We therefore refer the interested reader to "A Review of the Jurisprudence of the Khmer Rouge tribunal" by Robert Petit and Anees Ahmed (2010) who worked as prosecutors in the ECCC. The article by Philippe Gréciano is very short and focuses on the violation of the translation rights that Khieu Samphan suffered. Because his lawyer was French, Khieu Samphan chose French as language of work among English and Khmer. However, not only was the translation system of the ECCC not sufficiently developed to ensure the equality of languages but the legal authorities also did not comply with their obligations and were said to be manipulated. As a result, most of the documents in the Khmer Rouge case were not translated. With his paper, Philippe Gréciano aims to make translators aware of the kind of challenges described. Also, he argues for the reinforcement of the rights to translation, which requires for instance that the international criminal jurisdictions have access to specialized legal lexica.

\section{Concluding remarks}

Although language and law are inseparable, language anisomorphism is not the only challenging factor for legal translation and terminology because different countries with the same language develop distinct legal terminologies. In one way or another, all papers deal with the social aspect of legal discourse; most of the papers deal with the tensions that the co-existence of different legal discourses create due to the intensification of the cooperation among legal cultures; and some of the 
papers indirectly engage in the debate between universalism and cultural relativism. Jean-Claude Gémar and Abolou Camille Roger seem to believe that legal culture worldwide is tending to the universalism of law. Simon Taylor's article illustrates the difficulties of the European Union in passing uniform legislation (universalism) applicable to so many different Member States (relativism). Mathieu Devinat and Mathieu Guidère underline the importance of mastering different legal cultures (universalism vs. relativism). Philippe Gréciano argues for an international justice (universalism).

From our point of view, this volume of the RFLA directed by the legal expert, Philippe Gréciano, and the linguist, John Humbley, is more in line with Gémar and Kasirer's Jurilinguistique : entre langues et droits. Jurilinguistics: Between Law and Language (2005) than with Cornu's La linguistique juridique (1990). Firstly, the papers included mirror the definition of Jurilinguistics provided by Gémar: "la jurilinguistique est une réponse aux difficultés, aussi variées que nombreuses, que la cohabitation, sur un même territoire, des langues et des systèmes juridiques ne pouvait manquer de créer" (2005: xv). Secondly, they are collective and interdisciplinary works organized by both linguists and legal experts. We agree with Jean-Claude Gémar when he mentions in his article that the three works are all good practices of Jurilinguistics. As Jurilinguistics is well within the realm of applied linguistics and as most contributions are written by francophone authors, this number of the Revue Française de Linguistique Appliquée dedicated to language of law fully meets the aims stated by the directors in the presentation.

\section{References}

Cornu, Gérard 1990: La linguistique juridique. Paris: Montchristien.

Gémar, Jean-Claude (ed.) 1982: Langage du droit et traduction. Essais de Jurilinguistique./The Language of the Law and Translation. Essays on Jurilinguistics. Montréal: Linguatech.

Gémar, Jean-Claude/Kasirer, Nicholas 2005: Jurilinguistique: entre langues et droits. Jurilinguistics: Between Law and Language. Montréal/Bruxelles: Thémis/Bruylant.

ISO 1087-1: 2000: Terminology work - Vocabulary - Part 1: Theory and Application International Standards Organization. Legrand, Pierre 1999: Sur l'analyse différentielle des juriscultures. In Revue internationale de droit comparé 4, 1053-1071.

Maley, Yon 1994: The Language of the Law. In Gibbons, J. (ed.), Language and the Law. London/New York: Longman.

Petit, Robert/Ahmed, Anees 2010: A Review of the Jurisprudence of the Khmer Rouge tribunal. In Northwestern Journal of International Human Rights 8(2), 166-167.

Roche, Christophe/Calberg-Challot, Marie/Damas, Luc/Rouard, Philippe 2009: Ontoterminology: a new paradigm for terminology. In Proceedings of the International Conference on Knowledge Engineering and Ontology Development (KEOD 2009). Madeira, 321-326.

Šarčević, Susan 1985: Translation of Culture-Bound Terms in Laws. In Multilingua 4(3), 127-33.

Janine Pimentel 